\title{
Science and the (Meta)physical Body: A Critique of Positivism in the Vasconcelian Utopia
}

Durante su vida, el escritor y filósofo mexicano José Vasconcelos postuló que el mestizaje era la mejor manera de redimir al pueblo mexicano y latinoamericano. Según él, la fusión de sangres entre europeos, amerindios y negros engendraría en la región una humanidad estéticamente superior a la de sus progenitores raciales. Esta problemática aserción ha inspirado mucha crítica académica tanto en Latinoamérica como en Norteamérica y Europa. Si un tema destaca en estos estudios, son las paradojas inherentes a su paradigma racial. El pensador articulaba su filosofía del mestizaje a veces en términos científicos - pues la reproducción humana y la eugenesia no son más que expresiones de la biología - pero también imaginaba la hibridez racial como un avance cultural y social que trascendía simples cambios genéticos. A fin de cuentas, Vasconcelos subordinaba su pensamiento científico a la estética, de modo que un cambio en el genoma nacional representaría un mejoramiento metafísico del país. El presente estudio ofrece una lectura poshumana de su obra teatral Prometeo vencedor (1916?) y su ensayo La raza cósmica (1925) para demostrar que el avance genético constituye progreso estético en su pensamiento. Según Vasconcelos, el papel de la ciencia es el de mejorar estéticamente el mundo.

No thinker more fully embodies post-revolutionary Mexican racial attitudes than José Vasconcelos, the great proponent of Latin American mestizaje (Lund, Impure 108). The philosopher first publicly enunciated his "aesthetic" ideal of racial hybridity in Lima in 1916, and he would go on to write numerous texts on the subject that had a great effect throughout Latin America (Marentes 80). He spent most of the Revolution abroad, but returned to Mexico after President Álvaro Obregón invited him to head the country's education efforts. Vasconcelos founded the Secretaría de Educación Pública (SEP) and served as its first minister from 1921-1924. The government leader explicitly opposed both indigenismo and nineteenth century positivism on philosophical grounds (Skirius, Cruzada 21), but his work largely - and perhaps inadvertently - buoyed each of the aforementioned discourses by adding a metaphysical value to mixed-race identity (Sacoto 154-60). It is truly remarkable that his racial theory, which flirted with fascism (Sánchez Prado 390), also reverberated with the 
thought of such disparate figures as the communist muralists, the leaders of the modernity-driven capitalist state, and even Chicano activists in the Southwestern United States (Anzaldúa 77; Stavans 4-6, 11-13). At times Vasconcelos disapproved of how others articulated his ideas (Marentes 6o74); at others he compromised his aesthetic ideals with political pragmatism (Fell, Águila 216; Swarthout 119-21). ${ }^{1}$ Given his intellectual and political involvement in the post-revolutionary state, Vasconcelos became one of the most prominent Mexican letrados of the early twentieth century. ${ }^{2}$ In this article, I view his essay La raza cósmica (1925) alongside his play Prometeo vencedor (1916). ${ }^{3}$ After situating my argument within the existing scholarship on La raza cósmica, I provide a close reading of his play to show that Vasconcelos viewed science - when subordinated to aesthetics - as key to producing an improved humanity, and even posthumanity. ${ }^{4}$

If we adopt Thomas S. Kuhn's definition of science as a process where falsifiable observations are organized into paradigms (10-11), then it becomes clear that "doing science" requires a degree of disciplinary rigor that Vasconcelos lacks (Marentes 85). Instead, Vasconcelos posits an ideology of "aesthetics" that subordinates all forms of knowledge, including science, to classical standards of beauty ("Monismo" 91-93). As Michael Handelsman notes, "si bien la referencia a la ciencia parece tener la función de legitimar su Indología con bases empíricas ancladas en la racionalidad, lo que realmente prevalece en la propuesta de Vasconcelos son el ensueño y la nostalgia por una Castilla todopoderosa hecha trizas desde $1898^{\prime \prime}$ (40). The thinker invoked the scientific work of others to validate hispanista views of mestizaje across his work. In La raza cósmica, he reduces world history to a narrative in which different races have dominated global politics for a finite period of time before humanity advances and a new race takes over (Raza 5-13). The thinker built on botanical discourses of hybridity to extend, yet paradoxically reject, the work of the nineteenth-century English philosopher Herbert Spencer (Alonso 464). For Spencer, all human races had evolved to fit their natural habitats (26-29), but "the white man excels ... in moral susceptibility" (34). Vasconcelos concurred that humanity was constantly progressing, but he resisted Spencer's notion of European - particularly Anglo-Saxon - moral superiority, instead positing a great mestizo spirituality. Because the letrado believed in an ever-progressing humanity, he dialogued with the evolutionary paradigms of the day; as such, his work warrants a posthuman reading.

One underlying supposition of posthumanism is that it considers humanity to be an evolutionary phase that was born from protohuman 
ancestors. Thus it is only natural to assume that contemporary humanity will one day sire new posthumanities that take its place (Cochran and Harpending 1-10). For Vasconcelos, mestizaje ultimately remains in the human - rather than posthuman - sphere; however, because he views it as a quantifiable improvement to humanity, racial hybridity is prerequisite to transcending the human and creating a more perfect state of being. The thinker sincerely believed that racial hybrids would eventually become the hegemonic race as white criollos interbred with Amerindians and blacks. Despite this mixed heritage, mestizaje would not value all sides of the racial equation equally (Ortega 37-42). Indeed, Vasconcelos's belief that European hegemony resulted from superior racial practices led him to favor cultural forms that would Europeanize mestizo identity. ${ }^{6}$ The thinker constantly affirmed that the active role for indigenous subjects in ushering in a utopian humanity would be their sacrifice of both body and culture to the national cause by procreating a mixed-race state. ${ }^{7}$ Indeed, Vasconcelos expected Amerindians and blacks to knowingly and happily "redeem" themselves through a "voluntary extinction" that would occur as they bred with "superior" races and sired a (post)human future (Raza 27).

UTILITARIAN AND AESTHETIC MESTIZAJE IN THE POSTREVOLUTIONARY STATE

The thinker's aesthetic justification for mestizaje differed from that championed by the post-revolutionary state, which primarily employed racial hybridity as a discursive tool for incorporating indigenous populations into the workforce (Taylor and Yúdice 311). It is for this reason that Betsabé Arreola Martínez argues that "Vasconcelos jug[ó] un papel fundamental al otorgarle una dimensión filosófica, histórica y antropológica de la heterogeneidad étnica, mediante la incorporación de los pueblos indígenas a la vida civilizada haciéndolos mestizos" (4). Vasconcelos did not want to undertake indigenista projects, and he certainly did not wish to build a capitalist state following the US model. Nevertheless, in fetishizing racial miscegenation, the thinker aligned himself with the post-revolutionary state's official mestizaje - and its utilitarian focus. At the same time, official mestizaje came to embrace Vasconcelos's redemptive discourse, thus ascribing metaphysical, nationalistic value to a previously utilitarian movement. The two visions of racial hybridity were thus conflated as one functioned in practice and the other as a philosophical and ideological explanation of national character. The final sentence of the introduction to La raza cósmica states: "[Ll]egaremos en América, antes que en parte alguna del globo, a la creación de una raza hecha con el Tesoro de todas las anteriores, la raza 
final, la raza cósmica" (35). Far from merely justifying the incorporation of darker-skinned Mexicans into the economy, Vasconcelos viewed racial miscegenation as necessary to redeeming the nation's soul. This spiritual dimension, with its clear allusion to progress, fit naturally within the official discourse of a state that fetishized industrialization and "progreso" (Taylor and Yúdice 310-11).

The thinker's close association with the modernity-driven, postrevolutionary state meant that his racial philosophy would inevitably interface with scientific discourses. This is especially noteworthy because Vasconcelos's most visible ideological battle was against positivism, a discourse that took hold during the Porfiriato (1876-1910) (Quintanilla 195200; Zea, Precursores 117). For Charles Hale, positivist politics' "principal characteristics were an attack on doctrinaire liberalism, or 'metaphysical politics,' an apology for strong government to counter endemic revolutions and anarchy, and a call for constitutional reform" (27). The quest for objective truths produced institutionalized favoritism toward scientific knowledge. Abelardo Villegas argues that this led to serious hubris and assertions of scientific superiority "que nunca defendió la ciencia siempre cautelosa, sino los cientificistas, los positivistas" (Autognosis 11). For this very reason, positivism was vulnerable to critiques from humanistic and metaphysical viewpoints. The positivists, however, simply discredited and ignored those philosophers who challenged them. This outright rejection of metaphysical knowledge led Vasconcelos and several intellectuals from his generation to form El Ateneo de la Juventud, an organization that advocated humanism over positivism. The members of the organization held very different political and ideological views: some supported Porfirio Díaz, while others supported Venustiano Carranza, Francisco I. Madero, and even Victoriano Huerta (Crespo 71-73). However, they coincided in their critiques of positivism and their desire to disseminate humanistic knowledge throughout the nation. Vasconcelos asserted that "la relatividad del conocimiento científico, invadiendo las soberanas esferas de la filosofía, transformaba los principios lógicos, la moral y el gusto, y todo el pensamiento" (Monismo 91-92). Humanity could only overcome the resulting "spiritual plague" as it de-emphasized science in favor of "aesthetic monism," or a symphony of discourses that did not favor one form of knowledge over another (Monismo 91-93).

Vasconcelos's opposition to positivist education almost certainly took on a personal dimension; his decision to study law came about only because positivist forces had removed philosophy from university curricula (Jaén xx). Given his historical antagonism toward positivism and the sciences, many critics have interpreted the philosopher's aesthetic 
monism as a form of anti-science (Foster 66-67; Garrido 76). These studies rigorously show how Vasconcelos challenges scientific paradigms and knowledge throughout his work, and they prove invaluable to understanding his thought. Hale, however, asserts that Vasconcelos "repudiated positivism, except in aspects of his social thought" (259). As such, Vasconcelian politics - at least within Hale's view - would become the post-revolutionary state's newest incarnation of positivism. ${ }^{8}$ Hale is right to recognize certain congruencies between Vasconcelos's thought and that of his positivist forebears. Joshua Lund, for example, notes that Vasconcelos's racial discourse followed in the footsteps of the Porfirian cientificos by serving as "an effective articulation of race and time that helps to reconcile the hegemony of the nation with the sovereignty of the state" (Impure 108). Vasconcelos's allusions to evolution theory - even in light of his violent rejection of Darwinism, and especially Spencerism (Raza xv; Stavans 16-17) - for example, placed him in conversation with the scientific discourses of the day, while his ideal of corporeal "progress" invoked the positivist notion of using science to "improve" society. Clearly, Vasconcelos's anti-positivism grew out of the intellectual tradition of the nineteenth century.

Vasconcelos frequently and paradoxically turned to scientific discourse to buoy his anti-positivist ideas. This led to "an often unwieldy interdependence of the mystical and the material" within Vasconcelos's writings that makes it especially difficult to place him ideologically (Miller 29). Jerry Hoeg clears up some of the confusion by referring to science as "an 'over there' within the Raza cósmica [and by extension the author's entire oeuvre], an other that must, at some point, emerge" (76). ${ }^{9}$ Science necessarily sits at the heart of Vasconcelos's writings, but its role is one of catalyzing a metaphysically perfected, utopian (post)humanity. In this article I further develop Hoeg's "over there" by showing how Vasconcelos carefully crafts a utopian philosophy in which science plays a key, supporting role in the aesthetic politics of continued human evolution. ${ }^{10}$ My study differs from older studies on Vasconcelos - like those of Alberto Zum Felde (419-29) and Jaime A. Giordano (545-48) - that emphasize the metaphysical dimension of Vasconcelos's thought but ignore the role of science beyond that of ideational antagonist. ${ }^{\text {Il }}$ Vasconcelos viewed scientific discourse as a necessary component of his metaphysics. ${ }^{12}$ Indeed, he believed that his work would bridge the gap between philosophy and the sciences and signal a "proper," aesthetic path for Mexico, Latin America, and the world (Jaén xix).

The philosopher's primary goal was to place all types of human knowledge - ranging from science to the humanities - in their proper place. 
He frequently recurred to scientific discourses to give further credence to his mixed-race utopias. For example, La raza cósmica begins with the assertion that geologists now recognize America as the site of Atlantis (3). This (pseudo)scientific argument suggests a forever utopian element, as well as an ancient archeological prestige and culture, in Latin America (Grijalva, "Vasconcelos" 336-37). Here we must amend Octavio Paz's assertion that "el tradicionalismo de Vasconcelos no se apoyaba en el pasado: se justificaba en el futuro" (166). Instead, we can more precisely state that Vasconcelos justified his vision of Mexico and Latin America through utopian discourses centered both on the region's past grandeur and future potential. When theorizing utopias, Ruth Levitas notes a special "function" in which a future (or past) society becomes "a kind of goal" (Concept 6). What is more, utopia becomes a "method" for facilitating the "imaginary reconstitution of society" (Levitas, Method xiv). Levitas's approach allows us to gauge how Vasconcelos used notions of both past and future to create a regional ideal that appealed to readers from all over Latin America. Within his world, eugenic and technological advancements would work hand-in-hand with enlightened, lettered philosophies to catalyze a truly "cosmic" race. Once again we see a potential for the reconciliation of scientific and humanistic knowledge, but any attempt at this must recognize the primacy of the metaphysical.

This tension between science and spirit played out dramatically in Vasconcelos's tenure with the SEP. The Secretary of Public Education aimed to provide identical educational opportunities to all Mexican children regardless of race, so he opposed teaching indigenous children in their native languages (Fuentes 124). However, certain (neo)positivists, particularly Manuel Gamio, undertook indigenista initiatives that aimed to incorporate Mexican Amerindians into the state by tailoring education to the population's needs. Faced with this reality, Vasconcelos compromised his mixed-race aesthetics and authorized indigenista policies "because he feared that the SEP would lose its mandate for indigenous education to the 'scientists' in the Department of Anthropology" (Swarthout 119). This resulted in two oppositional government ministries with mandates to assimilate the indigenous population. The SEP advocated a cleansing of the Spirit, while Gamio's Department of Anthropology favored science and secularism (Swarthout 120; Fell, Águila 221). ${ }^{13}$ The disagreement between the secretaries of education and anthropology probably cost the country a great deal of resources and direction as it attempted to assimilate its Amerindians. Furthermore, the at times contradictory government agencies sent mixed messages regarding the means and reasons for assimilation to rural Mexicans. Gamio and Vasconcelos positioned science 
differently in their writing due to how they viewed positivistic discourse. As Ignacio M. Sánchez Prado argues, "para Gamio, buen heredero del positivismo, correspondía a la ciencia el desarrollo de la nación, y el mestizaje se refería simplemente ... a la integración del indio a la vida nacional por medio de los instrumentos de la antropología moderna" (386). Sánchez Prado further argues that Vasconcelos viewed mixed-race identity as "una promesa histórica construida de la validación del mestizaje como eje político cultural" (387). Thus the philosopher emphasized the metaphysical, utopian value of mixed-race identity, while the anthropologist sought only to use science to objectively modernize the state. These differences most certainly informed the decision of both men to found oppositional missions within their secretariats to address the socalled "Indian Problem." Vasconcelos and Gamio differed in key ways, but both paternalistically engaged indigenous Mexico and prescribed the means through which they could overcome their supposed primitivity and assimilate to a modern state.

Despite Vasconcelos's focus on the spirit, we should not dismiss his racial thought as wholly unscientific. The author clearly wished to engage with positivistic discourses - albeit from a humanist perspective - in order to reframe the knowledge that these produced. This was most obvious regarding eugenics, which was an accepted paradigm within European particularly British, German, and North American - circles long before Vasconcelos would ever put the pen to the page (Stepan 8). Many contemporary historians, intellectuals, and critics severely criticize the scientific racism of the early twentieth century, but few would go as far as to label it as a pseudoscience; instead, they generally cite more recent scientific advances that have disproven older paradigms (Stepan 5). Vasconcelos generally upheld the ideas behind white supremacist eugenics, but by rearranging his observations and inventing a new history of racial progression, he inscribed mestizaje, rather than whiteness, as the eugenic ideal. Sánchez Prado warns against taking La raza cósmica seriously, saying instead that the thinker utilized the genre of the "ensayo utópico" to posit mestizaje as a political strategy to articulate Latin American diversity - and unity - that serves as a precursor to transculturation, heterogeneity, and even hybridity ("Mestizaje" 382-83; see also Sobrevilla 21-23; Klor de Alva 254-58). This is not to say that Vasconcelian (and statist) views of mestizaje were benign discourses. As it aimed to aesthetically "improve" indigenous people by transforming them into mestizos, the discourse was also necessarily paternalistic, racist, and elitist.

Vasconcelos's elitism fits within the current of early twentieth century 
Latin Americanist thought that struggled to imagine how the region could maintain its autonomy in the face of a politically and economically aggressive United States (Sánchez Prado 381-97; Introna 97-125; Zea, Precursores 118). José Enrique Rodó, one of the founders of the movement, "admired" North American (read: New World Anglo-Saxon) pragmatism's ability to revolutionize and modernize the United States (51), but he also asserted that the country's utilitarianism had left it morally bankrupt (4650). Rodó prescribed inward meditation and reading the classics particularly the works of the Greco-Roman tradition - as the best way to resist Yankee materialism (9-30). ${ }^{14}$ Vasconcelos concurred with Rodó that US imperialism posed a threat to Mexican society; nevertheless, Juan Carlos Grijalva notes that he moved beyond Rodó by heading an intellectual effort to reconcile his nation with its racial past ("Introducción" 9)..$^{15}$ Prometeo vencedor exalts the classics by creating a futuristic world steeped in Greek mythology, but it also builds on and contributes to Mexican discourses of mestizaje that Rodó largely ignored. Thus Prometeo vencedor is a literary work that invokes Latin Americanist ideas with a distinctly Mexican flavor. Claude Fell decries the play's low quality (Fell, "Ideario" 550), but the work provides fascinating insights into the writer's thought. Given Prometeo vencedor's intricate nature and deep intratextual ties to La raza cósmica, it is surprising that the academy has largely forgotten it. Both texts represent different periods in Vasconcelos's life and career. ${ }^{16}$ The essay came out shortly after his tenure with the SEP. It preceded his failed presidential run by only four years, but the writer published his play before embarking on his career in the public sector. ${ }^{17}$ Rather than emphasize mestizaje as a political strategy as in La raza cósmica (Palou 14), this earlier text couches mixed-race identity primarily in aesthetic terms. This shift in focus allows for fresh perspectives regarding the key role Vasconcelos imagined for science in bringing about a spiritual, utopian rebirth of humanity.

POSTHUMAN PRESENCES IN PROMETEO VENCEDOR

Vasconcelos dedicates the majority of his three act play to three principal characters: Prometeo, Satanás, and a philosopher who is later reincarnated as Saturnino. María Sten categorizes the work as "más filosófica que dramática" (42), a fact that rings particularly true given that the play was never staged. Sarah J. Townshend, however, asserts an implicitly dramatic nature to Prometeo vencedor because its form forces its readers to stage the experience in their own minds (6o). Her argument suggests that we can use theories of performance to interpret the play. A brief plot summary will facilitate the discussion of its treatment of race and scientific 
discourse. The first act begins when Satanás finds Prometeo sitting between Popocatépetl and Ixtaccihuatl, the two famous volcanoes that separate Mexico City and Puebla. After a long conversation, a recently deceased Latin American philosopher appears on his journey to the afterlife; he proclaims that the people of Latin America will resolve their problems by embracing racial hybridity. The second act shows a renaissance that takes place one thousand years after the first act. Racial hybridity has spread throughout the world, and the philosopher has been reincarnated as Saturnino. He proclaims that humanity will finally transcend the body by refraining from reproduction. Outside of a few "mujeres feas," everyone agrees to Saturnino's philosophy. In the final act Satanás, Prometeo, and Saturnino reunite years later in the Himalayas. The aging philosopher, now a hermit, is one of only three human beings left on earth. He awaits a signal from the other two - who live in America and Africa - via a contraption of bells on strings. None come; he concludes that the human spirit has progressed beyond the physical plane, and he dies. As soon as the philosopher falls to the ground, a "stupid" man dressed in a kangaroo skin enters the stage, stating that he is the child of the "ugly" women who refused to renounce reproduction. They had established a secret community and used a synthetic mist to evade that high-tech devices that Saturnino had used to search the globe for human life.

The way in which Vasconcelos's (imagined) actors embody mestizo subjects on the (imagined) stage elucidates some of the more confusing aspects of the thinker's cosmic race that no criticism has been able to fully reconcile or explain. For example, La raza cósmica posits four historical racial moments, and mestizaje appears as a new fifth race (33). Most of the criticism identifies mestizaje as Vasconcelos's fetishized "raza cósmica" (Lewis 179; Bowker 39; Hedrick 20; Ocampo López 156). This association makes sense; the thinker discusses his fifth race's aesthetic favorability moments before asserting that the cosmic race will be born in America, and there is a clear relationship between the cosmic race and racial hybridity. However, in the prologue of his essay, Vasconcelos claims to have named his text La raza cósmica because he lacked a better term for this fetishized entity (xv). This suggests that the final race exists beyond mestizaje - which was a term that existed long before he wrote the essay. Racial hybridity, then, is a necessary step toward achieving a sixth race that will succeed even mestizaje. This interpretation seems especially appropriate in Prometeo vencedor, where Saturnino attempts to create his "raza celeste" by ending the process of human reproduction (77). Here the cosmic/celestial race has no body; rather it is the posthuman entity that 
emerges as mixed-race people transcend their bodies through sexual renunciation.

The play shows mestizaje as a great genetic and spiritual improvement to humanity, but racial hybridity ultimately remains within the human sphere. The second act shows an established mestizo society that has spread across the globe. According to Townsend, Vasconcelos recognized that the transitionary period - or "political stage" in which letrados imposed mestizaje upon the masses - could be "messy," so he decided to take his (reading) audience well into the future, long after the resolution of any conflicts (57). The result is an emphasis on the superior humanity that has resulted from an aestheticized eugenics. Unlike the first and third acts, which take place in mountainous regions, this section of the play is set in a prairie with a purple sky and numerous marble benches. Townsend asserts that this domestication of outdoor space is especially noteworthy because indigenous subjects were frequently equated with nature (58). As such, the place of Amerindians is to be domesticated and incorporated into a classical, Greco-Roman world that upholds Vasconcelian norms of aesthetics.

This scene represents a singular moment in Vasconcelos's writing because it is here that he gives his fifth race a body. The most interesting aspect of this representation is its surprisingly heavy focus on gender and sexuality. Countless ninfas populate the stage, calling attention to their beauty by emphasizing their claims to whiteness. Townsend asserts that due to this scene, "readers of La raza cósmica can spare themselves the trouble of proving that mestizaje is really a code word for whitening" (59). However, the text complicates her assertion as the ninfas seductively invite Prometeo to frolic with them in following manner:

Somos blancas como el más limpio mármol, y al soltar los cabellos parece que un lampo de sol nos baña la espalda. Son nuestros labios rojas heridas donde la vida arde con ansiedades de brasa...

Otras somos blancas, con tinte azulado, más blanco que el de la rubia y más incitante; en nuestros labios hay la pasión que crea los infiernos y un licor que turba y no sacia. Las madejas de nuestros cabellos son como serpientes voluptuosas.

A otras nos ha bruñido el sol con sus rayos de oro, y abrigamos la potencia fina y profunda que alimenta las pasiones largas. (47)

This is hardly the discourse of a purely "whitened" society; the ninfas celebrate their racial complexion(s), which endow them with a seductive, mixed-race exoticism. Vasconcelos's Orientalization of the mestiza ninfas 
moves beyond Eurocentric notions of white and exotic femininity. Indeed, these women represent a new racial conjugation that would set them apart from twentieth century people, and particularly women, of any race. This is especially obvious with the bluish women, who - beyond clear ties to modernista discourse - serve as metaphors for the aesthetic possibilities of racial mixing.

The focus on female sexuality is telling here; the playwright represents his mestizas by appealing to ancient Greek mythology, which held ninfas to be minor gods. While not yet "cosmic," they bear the incremental physical and genetic improvements that are necessary for transcending the body. The ninfas are neither quasi-divine, posthuman subjects nor twentieth century humans, although their genealogy ties them more closely to humanity than to the utopic posthumanity of Saturnino's "raza celeste." Unlike the half-gods of Greek mythology, Vasconcelos's ninfas' "superior" physical bodies result not from a divine sire, but from the synergetic, interracial fusion of inferior progenitors. Their humanity rings clear as the play emphasizes their sexuality, which is a highly embodied act that Saturnino aims to overcome. The ninfas' articulation of an advanced humanity underscores the fact that Vasconcelos views beauty, education, and interracial sexual union as components of the same eugenic equation. After pursuing these aforementioned ideals for a millennium, his fictitious society has transcended almost all barriers to human progress. This play, then, advocates a very literal racial hybridity rather than simple whitening. Of course, the fact that everything must fit within European intellectual and cultural traditions suggests a degree of cultural - but certainly not phenotypic - whitening that was inherent to the Mexican brand of official mestizaje in general.

The ninfas' seductive quality is especially interesting when juxtaposed with Saturnino, who descends from a plane and enters the stage to further the aesthetic perfection of humanity. Mestizaje and interracial sexual unity are necessary to human development in Vasconcelos's mind, but Saturnino's work underscores the fact that mixed-race identity - like every racial era within Vasconcelian thought - is transitory. Aesthetic eugenics have created a body so perfect that humankind can finally move beyond the physical. The ninfas come to represent both the allure and the vices of mestizo identity; their proactive eroticism emphasizes the inherently sexual nature of mixed-race eugenics, which in turn focuses their identity on their bodies. Their seductive potential suggests that they are aesthetically "superior" to their ancestors of all races, but this superiority paradoxically comes as heterosexual males - who must now resist their sexual urges - objectify their "exotic" beauty. The ninfas never attain true 
subjectivity; despite their great desirability, they do not engage in meaningful discussions, and for the most part they remain in the chorus in the background. Somewhat paradoxically, then, these women's status as objects signals them as the crown jewels of the thousand-year-old mestizo project while their seductive qualities position them as serious threats.

As long as the ninfas are objects without agency, Saturnino can neutralize their subversive potential by instilling values of celibacy in his male disciples. The true danger to his utopia emerges when women become active subjects who deliberately reject the interests of the mestizo patriarchy. The playwright emphasizes this through the "mujeres feas," who, unlike the ninfas, are not supposed to win the affection of a heterosexual, male audience. Their ugliness makes them indifferent to Saturnino's aesthetics and leads them to resist his philosophies outright. As the first act ends, they enter the stage and argue with the philosopher, telling him that they wish to bear children, but Saturnino retorts that they will never find any man willing to procreate with them. Townshend notes a comedic aspect to this back and forth (6o); however, the fact that such a conversation produces humor testifies to a cultural referent that objectifies female voices. This male chauvinism takes on a racial dimension as it draws attention to these women's apparent ugliness, a trait that Vasconcelos racialized throughout his oeuvre. In La raza cósmica he states, "El mundo así está lleno de fealdad a causa de nuestros vicios, nuestros prejuicios y nuestra miseria" (26). Given his thesis on racial hybridity and the fact that (Europeanized) education will cure people of their aesthetic shortcomings, this quote equates ugliness with indigeneity (Spitta 334; Marentes 96). The fact that the state can educate such ugliness away also suggests that this "fealdad" is performative in nature, and a robust education can modify indigenous performativity and incorporate Amerindians into the body politic.

Much of the criticism regarding Vasconcelos's racial thought focuses on his aim of incorporating indigenous Mexicans into the mestizo state (Lund, Mestizo 24; Ocampo López 146-56). These studies certainly show us a great deal about post-revolutionary Mexico, but I concur with Sánchez Prado when he argues:

Esta fue la función que, a pesar de su problemática articulación de la raza y de sus coqueteos con el fascismo, La raza cósmica jugó en el siglo XX: una forma de teorizar la resistencia a las colonizaciones que han aquejado la historia del continente. Este sentido preciso es el que se pierde cuando se identifica el mestizaje como simple articulación del estado liberal mexicano y latino-americano. (390-91) ${ }^{18}$ 
Vasconcelos's admittedly paternalistic dream of incorporating his nation's indigenes sprang from his desire for Mexico's self-determination and modernization through a home-grown path. My reading of Prometeo vencedor extends Sanchez Prado's observations by showing how race colors even Vasconcelos's anti-imperialism. Similar to what we see in the letrado's seminal essay, ugliness results from a lack of education and a break from the "Spanish mold." But the playwright codes the "mujeres feas" as Anglo-Saxon by signaling their ties to Australia - a fact that contradicts many studies that argue that Vasconcelos saw (only) the indigenous and black components of pre-mestizo society as "ugly."19 Not only do these women disassociate themselves from mestizaje, but they also favor the less refined British - rather than Spanish - European tradition.

The ugly women's racial coding is not overly surprising when we recognize that Vasconcelos believed that Anglo-Saxons and Latins (Iberians) had conflicting racial missions (Raza 18; Zea, "Vasconcelos" 30). Because he never expected to stage the play, Vasconcelos turns to aspects like his characters' speech to signal them as hideous and other. Just as Vasconcelos argues that indigenous "fealdad" comes from a lack of knowledge in La raza cósmica, the ugly Anglo-Saxon women show no respect for classical philosophy, and opt instead for pragmatism. ${ }^{20}$ In response to Saturnino, who has told them that they are too ugly to seduce any men, they reply "iBuscaremos centauros!" (68). Their invocation of a human/animal hybrid in response to Saturnino's doctrine of celibacy underscores that these women do not rationally articulate their decision; instead, they turn to basic animal desires - at least within the framework of the play - that inform their understandings of happiness. Their shortsightedness belies a lack of cultural refinement that makes them unable to accept, or even understand, Saturnino's teachings. That they refuse to bring about an immaterial (post)humanity underscores how these Anglo-Saxons' lack of education speaks to a deeper, spiritual deficit vis a vis their mixed-race counterparts.

The confrontation between Saturnino and the "feas" in Prometeo vencedor plays Rodó's dichotomy of classical spiritualism and Anglo-Saxon utilitarianism out in a dialectic space. The women certainly frustrate Saturnino's plans to move humanity beyond the body, but they do so in a way that validates Saturnino's thought and not their own. Similar to the uneducated Amerindians of La raza cósmica, these women are ugly due to their (performative) ignorance. Their gender, coupled with their ties to Anglo-Saxon whiteness - rather than Iberian mestizaje - are the driving force behind their opposition to Saturnino's aesthetic utopia. Throughout his life, Vasconcelos perceived Anglo-Saxon ambivalence - and resistance 
regarding racial hybridity as a great injustice (Vasconcelos, "Racial Problem" 98-99; Stavans 26-28; Jaén xix). Indeed, anti-mestizo ideologies within the US threatened racially mixed countries like Mexico. Vasconcelos's attempts to philosophically subvert the suppositions that justified his country's continued marginalization should challenge twentyfirst century scholars to reevaluate his work now that nearly a century has passed since he wrote both Prometeo vencedor and La raza cósmica. Clearly, he stood at the fore of the anti-imperialist projects that opposed US incursions into Latin American politics and territories. One key way for him to do this was by theorizing, and validating, an authentically Mexican (and Latin American) identity that could pose as a counterweight to US hegemony (Handelsman 35). ${ }^{21}$ Of course, his invocation of mestizaje also reflected colonial structures of race that validated internal empire and the marginalization of non-Western peoples and cultures (Handelsman 36). What the thinker viewed as liberatory, then, posed serious threats to black and indigenous people from Mexico and Latin American.

THE ROLE OF TECHNOLOGY IN THE VASCONCELIAN UTOPIA

The "enlightened" Saturnino functions as an imperial figure who imposes his spiritual ideals on the world as a whole. This validates Regina Crespo's argument that "correspondía a los intelectuales el papel central en la formación de esta alma, principalmente porque, de acuerdo con el pensamiento vasconceliano, sólo los intelectuales podían ser tocados por el genio" (102-03). Vasconcelos's elitism justified even acts of coercion by intellectuals if this would "improve" the soul of the nation at large. In Prometeo vencedor, Saturnino uses technology to monitor and facilitate the spread of his doctrine across the globe. If we define science as positivism or even the Kuhnian notion of organizing observations into paradigms then it receives no mention in the play. This lack of any reference to the hard sciences, however, does not preclude Vasconcelos from theorizing the role of technology - one of the most obvious fruits of science - in his mestizo utopia. Regarding the role of science in the letrado's work, Villegas states, "Vasconcelos ... la postula como tránsito de salvación, como la revivencia del universo entero" (Filosofía 83). Vasconcelos used the term "science" to mean knowledge of all sorts, and he viewed aesthetics as the greatest of the sciences (Villegas, Filosofía 83). As such, the playwright believed that the physical sciences must ultimately become an aesthetic tool whose laws adhere to - and even revive - Westernized standards of beauty. Thus the end goal of science, far from producing "objective" facts, is the imposition of a supposedly self-evident, greater (post)humanity.

When Prometeo and Satanás arrive at Saturnino's Himalayan home at 
the beginning of the third act, they find him surrounded by strange apparatuses that signal his technical sophistication (70). The philosopher later explains that he and his disciples utilized specialized gadgets to determine that there were no more living humans on the planet. The implication here is that, if he would have found people somewhere, both he and his disciples would have approached them and preached the gospel of self-renunciation and abnegation. Technology, then, becomes a tool that helps letrado figures to impose their ideology on the masses. It aids Saturnino in imposing his posthuman superation of the body on the world by seeking out those people who either oppose or have not yet heard his ideas. Technology and science are not the end goal of Saturnino's world; rather, they represent the means through which the philosopher can catalyze a glorious posthumanity. Saturnino has not abandoned his aesthetic and political ideals for science; instead, he has incorporated this discourse into his message. He never reifies positivism, but he does rely on technological advancements to impose his (post)human identity on the globe.

Saturnino's coercive doctrine of corporeal superation underscores one of the central tenets to the playwright's thought, at least as represented in Prometeo vencedor: In order to ensure redemptive - rather than random evolution, letrado figures like Saturnino (or Vasconcelos himself) must advocate eugenics. Although Vasconcelos distances his eugenics from positivist, and even scientific, discourses by emphasizing aesthetics rather than biology (La raza 33-34), any manipulation of the human genome necessarily has biological repercussions. Science exists in the letrado's thought as a method and discourse of power that can aesthetically shape human heredity and create a utopic, posthuman existence. This is especially true in Prometeo vencedor, where Saturnino utilizes science and technology for coercion and surveillance. Vasconcelos advocates racial miscegenation as the primary vehicle for his success, but he recognizes that it will be difficult to govern people's sexuality without the help of ultra-modern, science-fictionesque devices that track human activities throughout the world. Science still remains in the background of his play as another "over there," but the emphasis on both technology and (forced) racial hybridity pulls the playwright's thoughts on science into focus far more convincingly than does his essay.

As metaphysics becomes the favored way of knowing, mestizo science improves beyond even that of imperializing forces. The first major - and probably unperformable - mestizo use of technology occurs during the second act when Saturnino arrives on the stage in his airplane. Given that the first airplanes successfully flew in 1903, less than two decades before 
Vasconcelos would publish his play, this grand entrance represents the pinnacle of world technology. The "ugly women" do not enter on any comparable machine, so we can also assert that Saturnino's entrance places him ahead of Anglo-Saxon culture both philosophically and technologically/scientifically. This racialization of technological privilege reflects Vasconcelos's view - which the post-revolutionary state would later adopt (Lund, Mestizo xi) - of mixed-race identity as the key to Mexican, and even world, modernity. People of other races remain on the margin, both technologically and aesthetically, as Saturnino proclaims the means by which he can advance the collective human consciousness beyond even mestizaje. At this point it becomes clear that primitive people - coded as Anglo-Saxons in this case - are not privy to the same technologies as Saturnino and his disciples. When Saturnino's contraption of bells and strings affirms that the hermit is the last living human, Saturnino joyfully proclaims that the souls of the former humanity "va[n] a celebrar su divorcio definitivo del mundo físico, para irse, ya libre, a los espacios eternos" (79). This celebratory speech effectively places the cosmic race within the posthuman sphere. Given that Vasconcelos wrote before posthumanism became an intellectual discipline, it is obvious that the thinker does not frame his play in such terms. The cosmic/celestial race of Prometeo vencedor reflects the platonic influences that inform this apocalyptic rejection of the body; nevertheless, posthuman theory sheds greater light on the underlying suppositions of Vasconcelos's Platonism. Saturnino's invocation of liberty and eternity draws attention to the fact that this apocalyptic moment marks the birth of something that transcends the human. ${ }^{22}$ What is more, this passage emphasizes the role of technology in facilitating the aesthetic projects of political elites; Saturnino could not have brought about this spiritual posthumanity without the aid of his inventions.

Of course, the appearance of the "stupid" Australian shortly after Saturnino's death poses serious questions to my reading by suggesting that even a technologically advanced society may be incapable of fully overcoming the body. When he first arrives on the stage, the Australian explains how his mother evaded Saturnino's coercive teachings when he states:

Nuestras madres lograron seducir a unos cuantos de los que éste [Saturnino] engañaba y con ellos se fueron a vivir ocultamente, a la región más fea y apartada del mundo; por las selvas del interior de la Australia. Allí fundaron un país y lo rodearon de una especie de niebla artificial que lo hacía invisible a los anteojos y aparatos de Saturnino ... Los hombres decían a menudo que aquello era horrible y 
se sentían asqueados, añoraban a Saturnino; pero todas las renegadas se mostraban felices. (83)

Saturnino's failure to impose his utopian vision on these dissidents - in spite of all of his technology - provides one of the most tantalizing puzzles of the entire work. What should we make of this surprise ending that apparently undermines the playwright's racial aesthetics? The obvious answer would be to determine what went wrong, but Vasconcelos never provides a satisfying explanation as to how these caveman-like subjects evaded detection. As such, readers of the playscript must interpret the text based on the few clues he provides.

There are two possible explanations for Saturnino's remarkable failure, both with their accompanying significance. On the one hand, perhaps the Australian is correct in asserting that these women's ability to conjure a mist truly did shield them from Saturnino's devices, thus allowing the matriarchal society to grow under his nose. On the other hand, perhaps the philosopher king's machines detected this Australian civilization but did not register its inhabitants as human. The first explanation evokes the highly gendered division of nature (feminine) and technology (masculine) that persisted even within the academy at least until Donna Haraway proclaimed cyborg feminism in the 1980s. If the "mujeres feas" have the ability to circumvent technology, then they represent a subversive threat by virtue of their gender. The latter possibility suggests that technology can (and did) distinguish the human from the nonhuman, which would in turn imbue science with the interpellatory role of designating bodies as either savable or lost to perdition. Given Vasconcelos's focus on the metaphysical rather than the technical, both of these factors probably contribute to the Australian society's successful seclusion.

One key to this Australian matriarchy is the women's ability to use their ties to nature to undermine Saturnino's technology. We have already seen that the "feminine" values of motherhood - rather than the "masculine" trait of sexual self-gratification - pose the greatest obstacle to Saturnino's doctrine of self-resignation and the end of procreation. This fact suggests that Vasconcelos views femininity as essentialistically incommensurable with the masculine experience, despite the fact that he favored a more liberated femininity than most Mexican men of his time (Franco 103). Within this argument, the fissures between these oppositionally gendered modes of experiencing humanity allow the "mujeres feas" to outwit technology by evoking nature. Saturnino's machines are incapable of seeing through the feminine mists because they 
are only programmed to operate within the patriarchy, so feminine nature becomes a blind spot. Just as these women's "innate" (read: natural) maternal instincts lead them to challenge Saturnino's philosophy of the body, their association with the elements undermines his ability to coerce them through technology. Viewed in this light, Saturnino's "tragic" failure would have been fully avoidable if he had contained these women. Indeed, the "mujeres feas" only become subversive when Saturnino fails to convert them to his cause. However, his failures result in the women kidnapping mates and leaving for Australia. This narrative supports an imaginary in which seductive, lustful women harm society by forcing men to give in to their sexual urges against their better judgment. Even when these masculine "victims" realize the error of their ways, they cannot return to Saturnino's fold. At this point, they are stuck in a matriarchal, Amazonian society from which there is no escape. The greatest tragedy of the ugly women's seductions, at least within the discourse of the play, is that they reproduce children with tenuous ties to humanity.

The play's conclusion posits an evolutionary fork in the road of the homo sapiens species. Saturnino and his disciples transcend their bodies and achieve a posthuman, disembodied consciousness, while the Australian's invocation of the caveman figure suggests he has de-evolved toward protohumanity. ${ }^{23}$ Writing on the philosopher's thought as represented in La raza cósmica, Mónica E. Scarano argues that "la intermixión racial ya iniciada en Hispanoamérica daría lugar - en la utopía de Vasconcelos - a otro mestizaje más complejo: el cultural, verdadera palingenesia para los desalentados espíritus latinos, frente al poderoso movimiento expansivo anglosajón" (142). By the play's third act, the dichotomy of mestizaje and Anglo-Saxon racial "purity" has reached a breaking point after persisting for over one thousand years. The world has reached a final judgment where humanity has either been transfigured as it embarks on a new, posthuman path or damned to revert to protohumanity. Beyond simply representing an inferior articulation of humanity, the Australians have now de-evolved to the point that neither Prometeo nor Satanás recognizes any human traces in them. Thus the play concludes with the ultimate redemption of the mestizo world and the equally dramatic condemnation of what remains of the decadent, postimperial Anglo-Saxon race.

Ultimately, Vasconcelos's great contribution to Mexican thought was not his opposition to positivism or even his imagination of a utopian cosmic race. Instead, his work is especially useful when viewed as a mythos that justified the new brand of post-revolutionary nationalism. My reading of Prometeo vencedor sheds light on certain aspects of 
Vasconcelian thought where the existing criticism could not. I have shown that the writer imagined a scientific discourse that adhered to strict metaphysical guidelines. Equally informative, I have corroborated and further explained the triumphant discourse that the thinker associated with ongoing human evolution and progression. Beyond a political strategy, Vasconcelos represented mestizaje as the most eugenic articulation of humanity heretofore created. This position had such serious consequences - particularly in the indigenous and Afro-Mexican sectors of society - because the thinker's prominence allowed him to largely define the terms for race relations in post-revolutionary society. He was a pioneer in problematically asserting mestizaje as an evolutionary advancement of humanity, and it is significant that he ascribed a key role to technology in the creation of a mixed-race utopia. It is doubtful that Vasconcelos catalyzed this focus on technology and the body with his obscure closet drama, but he clearly tapped into a hidden part of the collective Revolutionary and post-revolutionary psyche as he imagined Saturnino's science-fictionesque utopia.

University of North Carolina, Charlotte

\section{NOTES}

$1 \quad$ Fell's book, José Vasconcelos: Los años del águila, discusses Vasconcelos's cultural missions in rigorous detail. See also Joaquín Cárdenas Noriega 59-99.

2 In La ciudad letrada, Angel Rama describes the letrado as a writer who has engaged with Latin American politics since colonial times.

3 The play's exact date of publication is unknown. In a 2010 publication of $L a$ raza cósmica, Editorial Porrúa lists the play's publication date as 1916 (xiii); however, the title page of an early publication of Indología dates the play as late as 1921. According to Didier T. Jaén, it was published in 1917 (xxii).

4 The French anti-positivist Henri Bergson greatly influenced Vasconcelos's thought and led him to believe that no philosophy was complete if it ignored recent scientific advances (Vasconcelos, "Bergson" 239). As he adapted the Frenchman's philosophy to the Mexican context, Vasconcelos produced the theory of aesthetic monism, which subordinated all forms of knowledge to metaphysics. See Patrick Romanell 503-08.

5 When not subordinated to aesthetics, science would produce what Vasconcelos termed "barbarie con técnica" (Comunismo 44-62).

6 For a discussion on Vasconcelos's attempts to teach the indigenous population to read by exposing them to classical literature, see Javier Garciadiego 179-91. 
7 I focus primarily on the thinker's relationship to the indigenous population, but Marco Polo Hernández notes Vasconcelos's ambivalence toward AfroMexicans as well (70-74).

8 Henry C. Schmidt states that positivism remained in force in rural areas following the Revolution; however, urban centers started repudiating it during these years (178).

9 Hoeg builds on the work of Antonio Benítez Rojo, who asserts an "over there" within Caribbean tradition that can be either repressive or liberating. Whereas Benítez Rojo refers principally to racial identities (290), Hoeg extends the definition to explain science's problematic role in Vasconcelian thought.

10 Acosta Rico notes that Vasconcelos turns to ancient Greece in an attempt to emphasize his metaphysical preoccupations over the positivistic (22-24). Hernán G. H. Taboada, however, disagrees, noting that much of Vasconcelos's aesthetics resulted from his time in Asia, which was another region with a great mestizo tradition (112).

11 Zum Feld briefly mentions that Vasconcelos included the teaching of science within his curriculum as Secretary of Public Education (429).

12 Anastacio Sosa Ramos argues that Vasconcelos recognized the importance of science in his education campaigns, but that he also made sure to include philosophical knowledge in his curricula (137-40).

13 Tace Hedrick notes that Vasconcelos and Gamio often worked together, with the latter becoming undersecretary of the SEP (39-40). Alonso also asserts a great deal of ideological common ground between them (466-69).

14 For an in-depth discussion of Rodó's influence on Vasconcelos's work, see Regina Crespo 97-99.

15 The threat of Anglo-Saxon imperialism was a major element in Vasconcelos's early writings (Crespo 252-54; Vizcaíno 196-98). Indeed, in his book ¿Qué es el comunismo? (1936), Vasconcelos argued that the Spanish Republic would have ushered in the ultimate destruction of the Anglo-Saxon race and the exaltation of Hispanic society if it had not been impeded by the Communist elements in their ranks (91-92). Faced with the threat of communism, the writer later justified US anti-communist incursions in sovereign countries.

16 Monsiváis sees Vasconcelos as a figure who began on the left - he was one of Madero's biggest supporters - but who would ultimately "exalt" fascist regimes following his devastating electoral defeat in 1929 ("Notas" 356). Marco Polo Hernández, however, argues that Vasconcelos espoused "extreme right tendencies" even while writing La raza cósmica (65).

17 The presidential campaign of 1929 wore Vasconcelos down; the ordeal culminated in his loss due to electoral fraud (Sherman 23). For an in-depth biographical look at his presidential run, see José Joaquín Blanco 146-68. 
18 Miller affirms this sentiment when she states, "Against the backdrop of the ideology of white supremacy and superiority in Europe and the United States, Vasconcelos' comments were radical and innovative, despite the obvious privileging of Western culture and the implicit deprecation of indigenous and black factors which would be 'improved' and 'instructed' by admixture with whites" (34-35).

19 Vasconcelos saw indigenous cultures and Anglo-Saxon imperialism as serious threats to both Mexico and Latin America. See Mónica E. Scarano 143-46.

20 This may be a literary echo of his own childhood; because he attended school in Eagle Pass, Texas, Vasconcelos found himself constantly facing anti-Mexican racism. This early experience led him to distrust the US in its dealings with his country. See Alonso 463-65.

21 Gabriella De Beer detracts from this understanding as she argues that Vasconcelos saw US (Anglo-Saxon) and Mexican (Latin American) cultures as two opposing articulations of humanity that, when joined, "would form a solid basis for a bright future" (275).

22 Vasconcelos espoused platonic views of the body throughout his life. In 1957 he wrote, "el alma se reconoce en su origen, la célula viviente, y se asquea" ("La BH" 969). He continued: "prefiero ver a mi prole consumida en las hogueras de la B-H [hydrogen bomb] y no dejarla sometida a la posibilidad de un mundo de esclavitud y de crueldad como el que 'fundamentan' los soviéticos. El último grito del alma es el centro de las fisuras cósmicas, será de júbilo, porque ya se encuentra apta para un mundo mejor que el que preside el Anticristo" (970). He asserts platonic views in both cases, but he reconciles his aesthetics with fascist thought in this latter text as he exalts the destruction of humanity as a better alternative than the adoption of a Soviet-style society.

23 Beyond its allusions to posthuman theory, the oppositional fates of the AngloSaxon and mestizo worlds invoke the binary of "Lo absoluto," and "La nada," the two Bergsonian poles of human experience (Vasconcelos, "Bergson" 24347). Whereas "lo absoluto" invokes "el triunfo de la conciencia sobre la anchura infinita del Cosmos" (Vasconcelos, "Bergson" 244), "la nada" is a state of being in which there are no ideas or higher brain function (Vasconcelos, "Bergson" 245-46). Vasconcelos's representation of these ideas through post and protohuman imagery is especially effective in capturing the essence of both conditions.

\section{WORKS CITED}

ACosta Rico, FA B IÁn. El pensamiento político de José Vasconcelos. Guadalajara:

Secretaría de Cultura de Jalisco, 2004. 
Alonso, an a maría. “Conforming Disconformity: 'Mestizaje,' Hybridity, and the Aesthetics of Mexican Nationalism." Cultural Anthropology 19.4 (2004): 459-90. AN ZA L D U A, GL O R IA. Borderlands/La frontera: The New Mestiza. San Francisco: Aunt Lute, 1987.

ARREOLOA MARTínEZ, BETZABÉ. “José Vasconcelos: El caudillo cultural de la Nación.” July 15, 2014. N. pag. Web.

B Enít E Z Rojo, AN T ONIO. La isla que se repite: El Caribe y la perspectiva posmoderna. Hanover: Ediciones del Norte, 1989.

B LAn Co, Jo Sé Jo a quín. Se llamaba Vasconcelos: Una evocación crítica. Mexico City: FCE, 1977.

B OW KER, PA U L. "Ibero-American Intersections: Constructing (Trans)National Imaginaries in Spain and Latin America, 1898-1938." Diss. U of Auckland, 2009. CÁRdenas noRiEga, JoA quín. José Vasconcelos: Caudillo cultural. Mexico City: Consejo Nacional para la Cultura y las Artes, 2008.

COCHRAN, GREGORY, AND HENRY HARPENDING. The 10, ooo Year Explosion: How Civilization Accelerated Human Evolution. New York: Basic Books, 2009. CRESPO, REGINA. Itinerarios intelectuales: Vasconcelos, Lobato y sus proyectos para la nación. Mexico City: UNAM, 2004.

DE BEER, GABRIELLA. José Vasconcelos and His World. New York: Las Américas Publishing Company, 1966.

FELL, ClAUd E. "El ideario literario de José Vasconcelos." Nueva Revista de Filología Hispánica 42.2 (1994): 549-62.

—. José Vasconcelos: Los años del águila. Mexico City: UNAM, 1989.

Foste R, DAVID William. Para una lectura semiótica del ensayo latinoamericano: textos representativos. Madrid: Porrúa, 1983.

FRAnco, J EA n. Plotting Women: Gender and Representation in Mexico. New York: Columbia UP, 1989.

FUENTES, R ocí o. “José Vasconcelos y las políticas del mestizaje en la educación." De Atahuallpa a Cuauhtémoc. Los nacionalismos de Benjamín Carrión y José Vasconcelos. Eds. Juan Carlos Grijalva and Michael Handelsman. Quito: Instituto Internacional de Literatura Iberoamericana, 2014. 115-46. gamio, manuel. Forjando patria: Pro-nacionalismo. Mexico City: Porrúa, 1916. GAR CIA DiE Go, JA Vi ER. "Vasconcelos y libros 'clásicos." De Atahuallpa a

Cuauhtémoc. Los nacionalismos de Benjamín Carrión y José Vasconcelos. Eds. Juan Carlos Grijalva and Michael Handelsman. Quito: Instituto Internacional de Literatura Iberoamericana, 2014. 179-99.

GAR Rid o, Luis. José Vasconcelos. Mexico City: UNAM, 1963.

GioRDANo, JA ImE A. "Notas sobre Vasconcelos y el ensayo del siglo veinte."

Hispanic Review 41.3 (1973): 541-54.

GRIJALVA, JUAN CARLos. "Introducción: Vasconcelos/Carrión, una democratización restringida." De Atahuallpa a Cuauhtémoc. Los nacionalismos de Benjamín 
Carrión y José Vasconcelos. Eds. Juan Carlos Grijalva and Michael Handelsman. Quito: Instituto Internacional de Literatura Iberoamericana, 2014. 7-28.

—. "Vasconcelos o la búsqueda de la Atlántida: exotismo, arqueología y utopía del mestizaje en La raza cósmica." Revista de Crítica Literaria Latinoamericana 30.6o (2004): 333-49.

HALE, CHARLES A. The Transformation of Liberalism in Late Nineteenth-Century Mexico. Princeton: Princeton UP, 1989.

HAND E LS MAN, Mi C HA L. "Visiones del mestizaje en Indología de José Vasconcelos y Atahuallpa de Benjamín Carrión." De Atahuallpa a Cuauhtémoc. Los nacionalismos de Benjamín Carrión y José Vasconcelos. Eds. Juan Carlos Grijalva and Michael Handelsman. Quito: Instituto Internacional de Literatura Iberoamericana, 2014. 31-57.

ha Ra Way, donna. Simians, Cyborgs, and Women: The Reinvention of Nature. London: Free Association of Books, 1991.

HED RICK, TACE. Mestizo Modernism: Race, Nation, and Identity in Latin American Culture, 1900-1940. New Brunswick: Rutgers UP, 2003. HERnÁndeZ, MARCo POLo. “The 'Afro-Mexican' and the Revolution: Making AfroMexicans Invisible Through the Ideology of Mestizaje in La raza cósmica." Publication of the Afro-Latin/American Research Association 4.4 (2000): 59-83. H O G, JER RY. Science, Technology, and Latin American Narrative in the Twentieth Century and Beyond. Bethlehem: Lehigh UP, 2000.

introna, an a maría. "Vasconcelos americanista." Revista Cuyo 7 (1990): 153-204. JAÉ N, DIDIER T. "Introduction." The Cosmic Race: A Bilingual Edition. Baltimore:

Johns Hopkins UP, 1997.

KUн N, тн ом As S. The Structure of Scientific Revolutions. 3rd ed. Chicago: U of Chicago P, 1996.

LEvit AS, RU Th. The Concept of Utopia. Frankfurt: Peter Lang, 2011. —. The Method of Utopia. New York: Palgrave Macmillan, 2013.

L U N D, J o S H U. The Impure Imagination: Toward a Critical Hybridity in Latin American Writing. Minneapolis: U of Minnesota P, 2006.

—. The Mestizo State: Reading Race in Modern Mexico. Minneapolis: U of Minnesota $\mathrm{P}, 2012$.

marentes, Luis a. José Vasconcelos and the Writing of the Mexican Revolution. New York: Twayne, 2000.

miller, marilyn GRACE. Rise and Fall of the Cosmic Race: The Cult of Mestizaje in Latin America. Austin: The U of Texas P, 2004.

MONSIVÁIs, CARLOS. "Notas sobre la cultura mexicana en el siglo XX." Historia

General de México. Vol. 4. Mexico City: El Colegio de México, 1976. 305-476. oCAMP O LÓPEZ, JAVIER. “José Vasconcelos y la educación mexicana." Rhela 7

(2005): 137-157. 
ORT E GA, GEM A. “Writing and Hybridity: Identity, Dialogics, and Women's

Narratives in the Americas." Diss. The U of Illinois at Urbana-Champaign, 2011. PALOU, PEDRO ÁNGEL. El fracaso del mestizo. Mexico City: Paidós, 2014.

PAZ, ос т A vio. El laberinto de la soledad. Posdata. Vuelta a El laberinto de la soledad. Mexico City: FCE, 2004.

QUin T A n l la, susana. Nosotros: La juventud del Ateneo de México. Mexico City:

Tusquets, 2008.

RAMA, Á G G L. La ciudad letrada. Montevideo: Arca, 1998.

ROD ó, JOSÉ E n R Q UE. Ariel. Barcelona: Red Ediciones, 2011.

ROMAnEll, PATRICK. "Bergson in Mexico: A Tribute to José Vasconcelos."

Philosophy and Phenomenological Research 21.4 (1961): 501-13.

SA с о т о, A т т n I o. El indio en el ensayo de la América española. New York: Las

Américas, 1971.

SÁ NCHE Z PRAD 0, IGNACio M. "El mestizaje en el corazón de la utopía: La raza cósmica entre Aztlán y América Latina." Revista Canadiense de Estudios Hispánicos (2009): 381-404.

SCARAN O, M ÓN ICA E. "La escritura de José Vasconcelos: Diseño de un modelo cultural." Texto Crítico 40-41 (1989): 139-49.

SCHMIDT, HENRY C. "Power and Sensibility: Toward a Typology of Mexican Intellectuals and Intellectual Life, 1910-1920." Los intelectuales y el poder en México. Los Angeles: U of California P, 1991. 173-88.

SKIR I US, J o H . José Vasconcelos y la cruzada de 1929. Mexico City: Siglo Veintiuno Editores, 1982.

sosa Ramos, anastacio. "El humanismo iberoamericano de José Vasconcelos." Humanismo mexicano del siglo XX. Tomo 1. Toluca: UAEM, 2004, 135-54.

SPE N CER, HERBERT. 1851. Social Statics. London: Georgte Woodfall and Son, 1851. Web.

SPit t A, SilviA. "Of Brown Buffaloes, Cockroaches and Others: Mestizaje North and South of the Río Bravo." Revista de Estudios Hispánicos 35.2 (2001): 333-47. stavans, Ilán. "The Prophet of Race." José Vasconcelos: The Prophet of Race. Ed. Ilán Stavans. New Brunswick: Rutgers UP, 2011. 1-44.

swa r th о т, ke l y R. "Assimilating the Primitive:" Parallel Dialogues on Racial Miscegenation in Revolutionary Mexico. New York: Peter Lang, 2004.

TAB OADA, hernán G. H. "Oriente y mundo clásico en José Vasconcelos." Cuyo. Anuario de filosofía argentina y americana 24 (2007): 103-119. Web.

TAYLOR, JULIE AND GEORGE YÚDICE. "Mestizaje and the Inversion of Social Darwinism in Spanish American Fiction." Literary Cultures of Latin America: A Comparative History. Volume III: Latin American Literary Culture. Subject to History. Eds. Mario J. Valdés and Djelal Kadir. Oxford: Oxford UP, 2004. 310-19. TOW NSEND, SARAH J. "The Unfinished Art of Theatre: Avante-Garde Intellectuals and Mass Publics in Mexico and Brazil." Diss. New York U, 2010. 
VAS C O N C L OS, J o SÉ. 1957. “La B-H.” El pensamiento de la reacción mexicana: historia documental 1810-1962. Ed. Gaston García Cantú. Mexico City: Empresas editoriales, 1965. 968-71.

—. Breve historia de México. Mexico City: Compañía Editorial Continetal, 1978. 10 Aug. 2014. Web.

—. "Bergson en México." Filosofía de Letras 2 (1941): 239-53.

—. Indología: Una interpretación de la cultura ibero-americana. Barcelona: Agencia Mundial de Librería, 1926.

—. Prometeo vencedor. Monismo estético. Madrid: Editorial América, [1920?].

—. ¿Qué es el comunismo? Mexico City: Ediciones Botas, 1936.

—. "The Race Problem in Latin America." José Vasconcelos: The Prophet of Race. Ed. Ilán Stavans. New Brunswick: Rutgers UP, 2011. 91-111.

—. La raza cósmica. 5 th Ed. Mexico City: Ediciones Porrúa, 2010.

VIL LE GAS, AB E LAR D o. Autognosis: El pensamiento mexicano en el siglo XX. Mexico City: Instituto Panamericano de Geografía e Historia, 1985.

—. La filosofía de lo mexicano. Mexico City: FCE, 196o.

VIZCAín O, FE RnA N D. "Repensando el nacionalismo en Vasconcelos." Argumentos 26.72 (2013): 193-217. Web.

ZEA, LE O P L D O. Precursores del pensamiento latinoamericano contemporáneo. Mexico City: SEP/Setentas, 1971.

—. "Vasconcelos y la utopía de La raza cósmica." Cuadernos Americanos 37.1 (1993): 23-36.

ZU M F E DE, A L B R TO. Índice crítico de la literatura hispanoamericana: Los ensayistas. Mexico City: Editorial Guaranía, 1954. 419-29. 